\title{
The Toothpaste Press: A Checklist
}

\author{
M I C H A E L P E I C H
}

The twelfth anniversary of Allan and Cinda Kornblum's Toothpaste Press will be celebrated in 1982. In these 12 years they have issued 118 titles in the form of books, chapbooks, pamphlets, and broadsides. The significance of this total becomes apparent when one realizes that 90 percent of their work has been produced letterpress, a much slower and more demanding type of production than high-tech modes of computerized typesetting and printing. Yet despite employing seemingly antiquated methods for making books, the production level of the press has risen steadily since 1970. Similarly, over the years there has been a corresponding growth in the Kornblums' talents for designing accessible and readable titles. But, as with most craftspeople, their success is the result of efforts which have involved an unending and enjoyable process of learning about their craft.

Allan Kornblum, who does most of the designing and printing for the press, came to The University of Iowa in July 1970 to attend the Writers' Workshop; as he describes it, he was en route to becoming an accomplished poet. By August he had issued the first volume of Toothpaste Magazine to encourage and recognize the talents of younger, lesser known poets like himself. But though he was now a publisher, he knew very little about typographic design and production. In order to familiarize himself with bookmaking techniques, he enrolled in Harry Duncan's typography course in September 1970, a step which enabled Allan to produce his first book, Famous Americans. Yet aside from this title and two others, and despite working with letterpress and hand composition in Duncan's courses, Kornblum continued to rely on mimeographed formats for the titles his fledgling Toothpaste Press issued. It wasn't until August 1972, when he moved to his present home in West Branch, Iowa, that Toothpaste titles began to appear regularly in letterpress formats. 
Part of the inspiration to use a hand technology may have come from the fact that the Kornblums bought Harry Duncan's old house, complete with a press room. More practically, though, setting their own type and printing the books themselves allowed them to control production and to print whomever they wanted. This was important because it encouraged writers who might not be published by commercial houses to use an accessible outlet like the Kornblums for their work. Thus the press became a logical extension of the spirit that founded Toothpaste Magazine. The Kornblums at the same time sharpened their appreciation for finely designed and well-made books, a tradition inherited from their association with The University of Iowa.

During the seventies, however, the Kornblums' allegiance lay more with writing poetry than publishing it; they were then at the center of actualism, an Iowa City literary movement that stressed the importance of common objects as worthwhile subjects for poetry. While their association with actualism shaped their poetry, it also helped to shape the design of the books they published. For example, the name Toothpaste derives from a fascination with the common object, this interest suggested in part by their press mark, which at first glance appears to resemble a capital $T$, or a set of teeth, but upon closer inspection depicts a pair of hands putting toothpaste on a toothbrush. The emphasis on objects, though, is most apparent in the books issued from the press, which are utilitarian and functional objects and not at all common.

Virtually all Toothpaste titles are cleanly designed, generally avoid distracting embellishments, and allow the type plenty of comfortable white space. The Kornblums' choice of text type favors those derived from early models of printing like Poliphilus and Centaur, and more modern faces like Goudy Modern and Perpetua; display faces range from the elegant Goudy Open to the more funky Flash Bold and Vaudeville. Just as varied are the papers they use, which range from subtle, unassuming sheets like Rives and Ingres-Fabriano to American machine-made papers from Strathmore and Curtis. Yet no matter what the physical properties may be, they function mainly to serve the text in a complementary way as vehicles for expression that add to the reading experience without distracting from it.

The Kornblums' efforts to wed text with design are clearly measured by the titles they have produced. In fact, to be fully appreciated, the items in the following checklist might be assembled chronologically and laid out on a table for perusal. The interested 
observer could then examine individual titles, measuring their design against other titles from the press, and ultimately gain an appreciation of the development of Allan and Cinda's talents for making books. For, during their 12 years as publishers, they have passed through many developmental stages ranging from making mimeographed books to finely made books. But in all their efforts the sense of the book as a functional object has been shaped by their growing knowledge of book production.

In the first three years of the press, the books that were produced were inspired by a desire to get words into print quickly and inexpensively; there was little emphasis placed on format. This is clearly evident in titles like Toothpaste Magazine, Tilt (1971), and the Brick Apartment (1973). In all three the text is presented in mimeographed form, since that was an inexpensive way to issue the volumes. A glimmering awareness of wedding text with design, however, is witnessed by the illustrative covers of Toothpaste Magazine and the letterpress-printed envelope for Tilt.

As they acquired more knowledge of production, they transferred this information successfully into the experience of making books. In this phase it is interesting to begin with the first letterpress book, Famous Americans (1971), and compare it with other early titles. Famous Americans is an amalgam of images, colored papers, and Futura type-the first attempt by Kornblum to execute a design that is shaped by text. When Waterworks was published a year later, Centaur text types replaced the bold Futura Book, and one text paper was used throughout. The net effect is to allow the text to speak for itself without being overwhelmed by visual distraction. This growing sense of design is exercised through many of the early letterpress titles, including The World Is God's T.V. (1973), The Don and Bill Company (1974), and Snapshots from Europe (1974), but it reaches fruition in Darrell Gray's Scattered Brains (1975). This is a book whose success is based on typographic design, on its combination of Basingwerk paper with Times Roman type to encourage a reading of the text; no tricks are used to get the reader's attention. Thus, each title in the comparison reveals the growth and change that was taking place as the Kornblums learned their craft and became more adept at matching type with paper, paper with ink, and design with text.

By 1974 they were working exclusively in letterpress and had begun to rely more on traditional solutions to the problems of design and execution. In the past seven years these skills have been refined to produce a series of carefully crafted and sensibly de- 
He spoke not a word, but went straight to his work, And filled all the pages; then turned with a jerk, And laying his pencil aside of his nose, And giving a nod, up the pages he rose. He sprang to his A, to his B's gave a C, And away they all flew like the down of a Z; But I read in the sky, ere he wrote out of sight, "Happy Alphabet to all, and to all a good write!"

Concluding stanza and illustration for A Vistt from St. Alphabet by Dave Morice. Published in 1980 by the Toothpaste Press in West Branch, Iowa. Item 52 in the Peich checklist. 


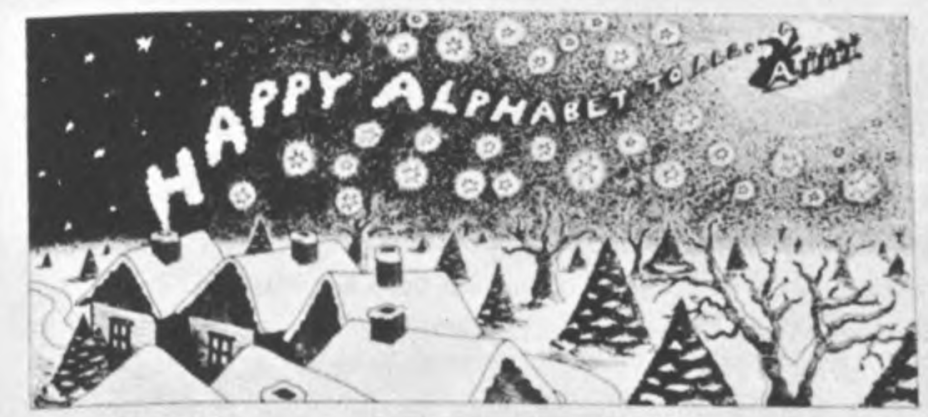


signed books. Not So Much Love of Flowers (1975) continues the sense of unobtrusive text design evident in Scattered Brains, but uses color to highlight titles and separate them from the text. The Candleflame (1976) contains on its title page and cover some of the earliest effective uses of illustrative material. The design of Young Anger (1979) is restrained, but it is made unique by the use of Flash Bold display type printed in red for the title page and the set-in initials of each poem. This book, like Reasons for the Sky (1979), Canciones (1980), and Awkward Song (1980), relies on more traditional typographic solutions to the design problems presented by the text. Yet within the framework of this more classical approach to bookmaking the Kornblums have managed to retain the qualities uniquely characteristic of Toothpaste titles. A pleasant example of this is Dave Morice's A Visit from St. Alphabet (1980), which is a delightful book that successfully weds straightforward text design set in Poliphilus with four-color renderings of the author's illustrations.

Perhaps the most successful year for the press, to date, was 1981. As a group, the titles issued represent some of the Kornblums' best and most consistent work. This is particularly evident in Carl Rakosi's Droles de Journal. The text and title page are cleanly designed in Bulmer text and Vaudeville display faces. The unlikely, yet successful, combination of these types attracts attention, but the reader is also drawn into the book by the repetition of a red border. On page one the border encloses a blank space; on page three it contains the title; and on page five it embraces the entire title page. For the reader, the cumulative effect of this border is to locate the position of the poems subliminally on the pages that follow. With a deft little stroke a solution is provided for the problem of placing text on a page. This same sensible and sensitive design that characterizes Droles de Journal is evident in the majority of the titles done this past year.

So, on the one hand, this checklist represents all the titles issued by a successful and growing regional small press. Yet it also reveals an interesting and practical chronicle of the development of accomplished bookmakers. From this perspective, the checklist is an exemplum of the process of cultivating and learning a craft. Ultimately, though, it is deserved recognition for work diligently and well done. One can only hope that the Kornblums will continue their work and make another checklist a necessity in 1994. 


\section{Toothpaste Press: A Checklist}

1970

1. TOOTHPASTE MAGAZINE No. 1, ed. by Allan Kornblum; August 1970. 38 unnumbered pages, $11^{\prime \prime} \times 8 \frac{1}{2}^{\prime \prime}$. Mimeographed on inexpensive paper. 200 copies stapled in blue offset wrappers; cover illustration by Carmella Yager. $\$ 1.00$.

2. TOOTHPASTE MAGAZINE No. 2, ed. by Allan Komblum; November 1970. 43 unnumbered pages, $11^{\prime \prime} \times 8 \frac{1}{2 \prime}$. Mimeographed on inexpensive paper. 200 copies stapled in blue offset cover stock; cover illustration by Pat Dooley; rear cover reproduces an Ivory Soap advertisement. $\$ 1.00$.

\section{1}

3. FAMOUS AMERICANS, by Allan Kornblum; January 1971. 20 unnumbered pages, $9^{\prime \prime} \times 6^{\prime \prime}$. Futura Book type on variously colored papers; illustrations by Pat Dooley printed offset. Printed as a project for Harry Duncan's typography class at The University of Iowa. No imprint listed. Copies distributed to friends of the printer.

4. TOOTHPASTE MAGAZINE No, 3, ed, by Allan Kornblum; February 1971. 56 unnumbered pages, $11^{\prime \prime} \times 8 \frac{1}{\prime \prime 2}$. Mimeographed on variously colored inexpensive papers, 250 copies stapled in white offset cover stock; cover illustrations in red by Pat Dooley. $\$ 1.00$.

5. TOOTHPASTE MAGAZINE No. 4, ed. by Allan Komblum; June 1971. 72 unnumbered pages, $11^{\prime \prime} \times 8^{1 / 2}{ }^{\prime \prime}$. Mimeographed on inexpensive paper. 300 copies stapled in pink offset cover stock; cover illustration in green by Pat Dooley; rear cover illustration in green by Jim Fink. $\$ 1.00$.

6. TOOTHPASTE MAGAZINE No. 5, ed. by Allan Komblum; September 1971. 70 unnumbered pages, $11^{\prime \prime} \times 8 \frac{1}{1 \prime}$. Mimeographed on inexpensive paper. 500 copies stapled in white glossy offset cover stock; cover photograph by Allan Kornblum. \$1.00.

7. VARIATIONS ON A THEME IN BLUE, by Rochelle Ratner; October 1971. Broadside, $15^{\prime \prime} \times 9 \mathbf{9}_{2}^{\prime \prime}$, folded in thirds. Octavian types in white on blue Strathmore Text paper. 300 copies in Domestic Etch folder, with three linoleum blocks in blue by Colin Andre. First letterpress publication with the Toothpaste Press imprint. \$1.00.

8. TILT: A COLLECTION OF POEMS AND SHORT STORIES, by Dave Morice; November 1971. 44 unnumbered pages, $11^{\prime \prime} \mathrm{x} 8 \mathbf{1}^{\prime \prime}$. Mimeographed on inexpensive paper; illustrations by the author. 450 copies in manilla envelope printed letterpress at the Nomad Press; cover drawing in red and blue by Pat Dooley. $\$ 1.00$.

9. TIGHT PANTS, by Allan Kornblum; December 1971. 24 unnumbered pages, $10^{\prime \prime}$ x 6\%". Futura Book type in brown on Beckett Text paper; four drawings in blue by Pat Dooley. 175 copies in 
gray Fabriano wrappers; cover drawing in orange, with title in brown. No imprint. $\$ 1.50$.

10. TOOTHPASTE MAGAZINE No. 6, ed. by Allan Kornblum; April 1972. 70 unnumbered pages, $11^{\prime \prime} \times$ 8 $x^{\prime \prime}$. Mimeographed on variously colored inexpensive papers. 500 copies stapled in wrappers printed letterpress in beige and gold; cover illustrations by Dave Morice. \$1.00.

11. GOLD RUSH, by Steve Toth; May 1972. 14 unnumbered pages, French fold, 8 $y_{2}^{\prime \prime}$ x 6". Weiss types on Mulberry paper. 115 copies, numbered and signed, in bronze Fabriano wrappers; title in gold on cover. Printed by Cinda Wormley Kornblum as a project for Harry Duncan's typography class at The University of Iowa. \$2.00.

12. SCROLL OF TWO POEMS, by John Giorno; June 1972. 9/2" x 13". Zinc blocks of author's handwriting in red on Chiri paper. 125 copies in scroll format tied with red ribbon. $\$ 1.00$.

13. TOOTHPASTE MAGAZINE No. 7, ed. by Allan Kornblum; July 1972. 90 unnumbered pages, $11^{\prime \prime}$ x 8\%". Mimeographed on inexpensive paper. 500 copies stapled in glossy white offset cover stock; cover illustration by Byron Burford. $\$ 1.00$.

14. THE 10th J, by Joyce Holland; August 1972. 12 unnumbered pages, $34^{\prime \prime} \times 2 \%^{\prime \prime}$. Bulmer types on wedding announcement tissue paper. 90 copies in white Fabriano wrappers. Joyce Holland is the pseudonym of Dave Morice. \$.50.

15. WATERWORKS, by Paul Violi; December 1972. 24 unnumbered pages, $10^{\prime \prime} \times 5^{\prime \prime \prime}{ }^{\prime \prime}$. Centaur types in black and blue on Beckett paper. 250 copies of first state of cover in Fabriano wrappers; 250 copies of second state of cover in Strathmore Beau Brilliant wrappers; both states have a linoleum block in blue by Cinda Kornblum on cover, with title in white. 50 copies, numbered and signed, in second state of binding. $\$ 2.00 ; \$ 4.00$ signed edition.

TIME WITH BIRDS, by Darrell Gray; January 1972. Broadside, $204^{\prime \prime \prime} \times 12^{\prime \prime}$. Centaur types in two shades of red; 100 signed copies on Fabriano Cover; excerpted from SCATTERED BRAINS. \$2.00.

A CIGARETTE IS A GLASS OF MILK, by Dave Morice; March 1972. Broadside, 6r" ${ }^{\prime \prime}$ × 20". Centaur types in black, red, and blue; 90 copies on Domestic Etch paper. \$1.00.

THE LIGHT SWITCH, by Joyce Holland; March 1972. Broadside, $10_{4}^{3 \prime} \times 5^{\prime \prime}$. Studio types in red and black; 100 signed copies on Strathmore Text paper. Distributed to friends of the press.

1973

16. THE MAD SHOEMAKER, by John Batki; February 1973. 38 unnumbered pages, $10^{\prime \prime} \times 8^{\prime \prime}$. Mimeographed on inexpensive paper. 300 copies stapled in white wrappers; linoleum block in black by 
Dave Morice, title in red on cover. 26 copies numbered and signed by author and artist. $\$ 1.00 ; \$ 3.00$ signed edition.

17. THE BRICK APARTMENT, by James Mulac and Allan Kornblum;

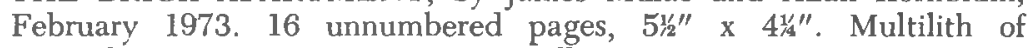
original manuscript on inexpensive yellow paper. 100 copies in white Japanese wrappers printed letterpress in red and black. $\$ 1.00$.

18. THE WORLD IS GOD'S TV: A Chapter of RANDALL HAMILTON, by Sheila Heldenbrand; May 1973. 8 unnumbered pages, 5/4" $\times 4_{4}^{\prime \prime \prime}$. Plantin types on Mulberry paper. 200 copies issued in either brown Fabriano or blue Strathmore wrappers, printed in Gallia types. A joint publication with the Cedar Creek Press. \$1.00.

\section{4}

19. SNOW, by Tomaz Salamun, translated from Slovene by the author in collaboration with Michael Waltuch, Anselm Hollo, Bob Perelman, Deborah Kohloss, and Elliott Anderson; December 1974. 70 unnumbered pages, $8 y^{\prime \prime}$ x 6 6 ${ }^{3 \prime}$. Mimeographed on inexpensive offset papers. 300 copies on beige wrappers printed letterpress in red; stenciled snowflake by Al Buck on cover, title in red. 26 numbered and signed copies, although author never numbered the signed edition. $\$ 1.50 ; \$ 3.00$ signed edition.

20. THE DON AND BILL COMPANY, OR, THE TELEPHONE WILL GET YOU WHAT WE WANT, by Jim Mulac; April 1974. 8 unnumbered pages, 2/2 $\gamma^{\prime \prime} \times 3^{\prime \prime}$. Garamond types in blue on Hammermill Safety paper. 100 copies in green wrappers; cover illustration in blue. Toothpaste Checkbook Number 1. The only number in the series. Copies distributed to friends of the press.

21. SNAPSHOTS FROM EUROPE: A TRAVELOGUE, by Dave Mo-

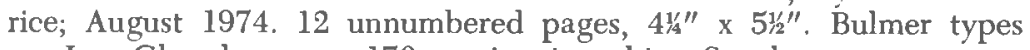
on Iyo Glazed paper. 170 copies in white Strathmore wrappers; cover in black, with illustration in brown. $\$ 1.50$.

\section{5}

22. SCATTERED BRAINS, by Darrell Gray; January 1975. 78 pages, $8^{\prime \prime} \times 6^{1 / 4}$. Times Roman linotype on Basingwerk Parchment paper; three photographs by Tim Hildebrand printed offset and tipped in. 575 copies in gray Fabriano wrappers; title in red on cover and spine. 50 copies, signed by author, bound in brownish/white cloth over boards; paper label on spine. $\$ 5.00 ; \$ 15.00$ signed edition.

23. DENTAL FLOSS, Vol. 1, No. 1, ed. by Allan Kornblum; March 1975. 16 unnumbered pages, $9^{\prime \prime} \times 6{ }^{\prime \prime \prime} "$. Centaur types in black and pale blue on Curtis Ragston paper. 375 copies in pale blue wrappers; cover illustration by Dave Morice. $\$ 1.50$.

24. THE WACKING OF THE FRUIT TREES, by Dick Gallup; September 1975. 16 pages, $5^{\prime \prime} \times 5{ }^{\prime \prime}$. Centaur and Rheiner Script types in black and green on Masa paper. 175 copies of first state of cover 
in yellow/green wrappers, with typographic design in green and black; 175 copies of second state of cover in pale green wrappers, with illustration by Jacki Gardner. $\$ 2.00$.

25. NOT SO MUCH LOVE OF FLOWERS: POEMS 1969-1972, by Allan Appel; November 1975. 36 unnumbered pages, 83" x $5^{\prime \prime}$. Plantin and Goudy types in black and red on Masa paper. 475 copies in orange Beau Brilliant wrappers; paper label in black and red on cover; title on spine. 26 copies, lettered and signed, bound in rust cloth over boards by the Black Oak Bindery; paper label in black and red on cover. First appearance of press mark designed by Pat Dooley. $\$ 4.00 ; \$ 15.00$ signed edition.

\section{6}

26. THREE NUMBERS, by Jim Hanson and Steve Levine; January 1976. 8 unnumbered pages, $5^{\prime \prime} \times 5_{4}^{\prime \prime}$. Centaur types in black and brown on Beckett paper; title in Coronet display in brown. 350 copies in white wrappers; title in black and brown on cover. $\$ 1.00$.

27. HAZEL \& OTHER POEMS, by John Sjoberg; April 1976. 46 pages, $10^{\prime \prime} \times 6 y_{2}^{\prime \prime}$. Bulmer types on Curtis Ragston paper; illustration in brown on title page. 450 copies in pumpkin brown Classic Laid wrappers; title in black and red on cover; title on spine. 50 copies, numbered and signed, quarter-bound in black cloth, with brown Tomoe paper sides by the Black Oak Bindery; paper label on spine. Designed by Cinda Kornblum. \$4.00; $\$ 15.00$ signed edition.

28. BANDWAGON, by Cinda Kornblum; April 1976. 16 unnumbered pages, 4 $4_{4}^{3 \prime \prime} \times 4_{2}^{\prime \prime}$. Plantin types on Curtis Ragston paper; title in Gallia display in red. 425 copies in white wrappers; cover illustration in red by Dave Morice. $\$ 2.00$.

29. THRESHOLD, by Allan Kornblum; June 1976. 16 unnumbered pages, 4" $\times 3^{\prime \prime}$. Bulmer types in black and green on Curtis Ragston paper. 700 copies in Fabriano wrappers; cover illustration in green by Dave Morice. $\$ 1.50$.

30. A BLUE TONGUE: A PAMPHLET OF POEMS, by Steve Levine; September 1976. 24 unnumbered pages, 7/2" x 5/2". Plantin and Bulmer types on Strathmore Beau Brilliant paper; title page in black and blue. 450 copies in blue Beckett Cambric wrappers; cover illustration by the author. $\$ 3.00$.

31. DENTAL FLOSS, Vol. 1, No. 2, ed. by Allan Kornblum; September 1976. 16 unnumbered pages, $9^{\prime \prime} \times 66^{\prime \prime \prime}$. Centaur and Perpetua types in black and brown on Curtis Ragston paper. 375 copies in light brown wrappers; cover illustration in brown by Dave Morice. \$1.50.

32. THE CANDLEFLAME, by David Hilton; Autumn 1976. 20 unnumbered pages, $8^{\prime \prime} \times 5_{12}^{\prime \prime}$. Bulmer and Crayonette types on Iyo Glazed paper; yellow flame illustration on title page. 750 copies in Beau Brilliant wrappers; linoleum block in orange and yellow by Elizabeth Zima on cover. $\$ 3.00$. 
33. THE NIGHT WE STOOD UP FOR OUR RIGHTS: POEMS 1969. 1975, by Morty Sklar; October 1977. 54 pages, 9 ${ }_{2 \prime \prime}^{\prime \prime}$ x 6". Perpetua types on Strathmore Beau Brilliant paper; title page in green, black, and red. 650 copies in yellow/green Strathmore Beau Brilliant wrappers; cover drawing in red by James Harrison; title on spine. 50 copies, numbered and signed, quarter-bound in olive cloth, with Sudare Olive paper sides by Black Oak Bindery; paper label on spine. $\$ 4.00 ; \$ 15.00$ signed edition.

34. HEAVY JARS, by Anselm Hollo; December 1977. 38 unnumbered pages, $8^{\prime \prime} \times 66^{\prime \prime}$. Plantin and Arboret types in black and brown on Strathmore Brigadoon paper; title page in brown, red, and black; frontispiece by Joe Giordano. 1,300 copies in red Beckett Cambric Duplex wrappers; cover drawing in black and brown by Pat Dooley printed offset; title in black and red on spine. 100 copies, numbered and signed, bound in red linen over boards by Black Oak Bindery; paper label in brown and red on front cover. $\$ 4.00 ; \$ 15.00$ signed edition.

PURPLE MIST, by Darrell Gray; May 1977. Broadside, 3\%2" x 131/4". Bulmer types in purple; 200 signed copies on mustard yellow/green Strathmore Beau Brilliant paper. \$1.00.

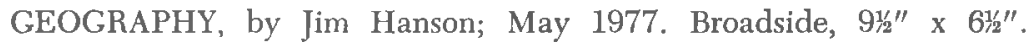
Perpetua types; 70 signed copies on Moetachi paper; most copies distributed free at a reading by Hanson, although a few sold for $\$ 1.00$.

\section{8}

35. VODKA AND ROSES, A NOVEL, by Michael Irene Welch; April 1978. 20 unnumbered pages, 6 $\mathbf{y}^{\prime \prime}$ x 6/2". Perpetua and Salem types in black and pink on Strathmore Brigadoon paper; frontispiece and cover illustration in red by Tom Welch, cut into linoleum blocks by Cinda Kornblum. 550 copies in pink Brigadoon wrapper. $\$ 2.50$.

36. LATER, by Robert Creeley; June 1978. 16 unnumbered pages, 83" $x$ 5 $x_{2}^{\prime \prime}$. Perpetua types in black and brown on Iyo Glazed paper; title page in black, brown, and orange, with drawing by Louis Picek. 800 copies in gold Strathmore wrappers; cover illustration in brown by Louis Picek. 100 copies, numbered and signed by the author and illustrator, in orange handmade Japanese wrappers; cover illustration in brown by Louis Picek. $\$ 3.00 ; \$ 15.00$ signed edition.

37. DENTAL FLOSS, Vol. I, No. 3, ed. by Allan Kornblum; September 1978. 16 unnumbered pages, $9^{\prime \prime} \times 6 / 4$. Centaur types in black and green on Curtis Ragston paper. 425 copies in pale green Strathmore wrappers; cover illustration in green by Dave Morice. $\$ 1.50$.

38. TRIPTYCH: FOR PEG, by Robert Dana; August 1978. Three folded pages, $10^{\prime \prime} \times 13^{\prime \prime}$. Perpetua types in black and red on Strath- 
more Grandee paper. 175 copies, numbered and signed, in three part accordion fold; title on front. Printed for The Wine Press, Chicago, Illinois.

39. PERIPATETICS, by Jonathan Greene. 34 unnumbered pages, 91/1" x 6". Bembo types on Beckett paper; title page in black and red. 700 copies in brown Beckett Text wrappers; drawing on cover by John Furnival; title in red on spine. 50 copies, numbered and signed, quarter-bound in brown cloth, with orange cloth sides. Printed for the Truck Press, St. Paul, Minnesota. \$5.00; $\$ 25.00$ signed edition.

IN DEFENSE OF PURE POETRY, by Edward Dorn; April 1978. Broadside, 5" $\times$ 71/" Perpetua types; 200 unsigned copies on Japanese handmade paper. 26 copies lettered and signed. Printed for the Truck Press. $\$ 2.00 ; \$ 12.50$ signed edition.

EIGHT MINUS EIGHT, by Jeffrey C. Wright. Broadside, 71/4 $\mathrm{x}$ $4 x^{\prime \prime}$. Perpetua types; 180 signed copies on Tairei Red paper; most copies distributed free at a reading by Wright, although a few sold for $\$ 1.00$.

\section{9}

40. TRANSMIGRATION SOLO, by Joseph Ceravolo; January 1979. 46 pages, $73^{\prime \prime} \times 5^{\prime \prime}$. Centaur types in black and orange on Strathmore Pastelle paper. 1,000 copies in orange Strathmore Text wrappers; cover illustration in black by Mona daVinci; title on spine. 100 copies, numbered and signed; quarter-bound in black cloth, with orange Japanese paper sides by Black Oak Bindery. Designed by Cinda Kornblum. $\$ 4.00 ; \$ 15.00$ signed edition.

41. REASONS FOR THE SKY, by Jim Hanson; March 1979. 20 unnumbered pages, $7 \pi_{4}^{\prime \prime} \times 4 \%^{\prime \prime}$. Plantin and Libra types in black and blue on blue Ingres-Fabriano paper. 900 copies in blue IngresFabriano wrappers; title in black, blue, and white on cover. $\$ 3.00$.

42. LITTLE MYSTERIES, by Ken Mikolowski; May 1979. 20 unnumbered pages, 6" $\times 4^{\prime \prime}$. Poliphilus and Blado types in black and burgundy on Mulberry paper; drawings by Anne Mikolowski. 800 copies in burgundy wrappers; cover illustration by Ann Mikolowski; each copy contains a bookmark. Offset edition of 2,000 copies on Strathmore Grandee paper, with same cover as letterpress edition, printed at Iowa City Women's Press. \$3.00.

43. YOUNG ANGER, by Rose Lesniak; October 1979. 20 unnumbered pages, 9/2" $\times$ 6". Perpetua and Flash Bold types in black and red on Strathmore Beau Brilliant paper. 800 copies in red Beau Brilliant wrappers; cover drawing in black by Tim Milk. $\$ 3.00$.

44. QUICKSAND THROUGH THE HOURGLASS, by Dave Morice; December 1979. 58 pages, 93" x 6*". Bulmer types on Curtis Rag paper; title page in black, gray, and yellow; illustrations in gray by the author; title page and cover $Q$ from a wood engraving by Al 
Buck. 1,000 copies in sandy yellow wrappers by Prairie Fox; title on spine. 100 copies, numbered and signed, bound in yellow cloth over boards by Black Oak Bindery; $Q$ in gray on cover. $\$ 4.50 ; \$ 20.00$ signed edition.

45. I NEVER WANTED FAME, by Antonio Machado, trans. by Robert Bly; May 1979. 20 unnumbered pages, 5" x 6/2". Bulmer and Homewood types in black and blue on Strathmore Pastelle paper; double spread title page, with scratchboard illustration in blue by Randall W. Scholes. 1,500 copies in light blue Curtis Tweedweave wrappers; dark blue Curtis Tweedweave endpapers; title and illustration on cover. 100 copies, numbered and signed, on Ragston, in Strathmore wrappers; 20 additional copies were signed and unnumbered, but not offered for sale. 26 copies, signed and lettered, on Ragston, bound in blue paper over boards, with paper label on cover; also signed by binder, Paul Feroe. Printed for the Ally Press, St. Paul, Minnesota. \$2.50; $\$ 8.00$ edition of $100 ; \$ 30.00$ edition of 26 .

46. THE WORK OF THE ICON PAINTER, by Mary Jane White. 24 unnumbered pages, $10^{\prime \prime} \times 6 \% "$. Poliphilus types on Curtis Rag paper; title page has vertical border in red of printer's devices. 500 copies in blue Strathmore Grandee wrappers; title page design repeated on cover. Printed for the Osiers Press, Iowa City, Iowa. \$3.00.

PEDAL POINT, by David Gitin. Broadside, 6" $\times$ 91/2". Poliphilus types; 200 signed copies on Dresden Ingres paper; most copies distributed free at a reading by Gitin, although a few sold for $\$ 1.00$.

1980

47. GONE SAILING, by Helen Adam; January 1980. 32 unnumbered pages, 10x" x 5 F $^{\prime \prime}$. Poliphilus types in brown and black on Gutenberg Laid paper; drawings by Ann Mikolowski. 1,000 copies in brown Strathmore Grandee Duplex wrappers by Prairie Fox; illustration on cover by Ann Mikolowski; title on spine. 150 copies, numbered and signed, bound in beige cloth over boards by Black Oak Bindery; paper label on cover. $\$ 5.00 ; \$ 20.00$ signed edition.

48. COUNTRIES, by Anne Waldman; February 1980. 32 unnumbered pages, $5^{\prime \prime}$ x 6\%2". Goudy Modern and Goudy Open types on pale green Strathmore Pastelle paper; linoleum blocks in green by Reed Bye. 900 copies in Strathmore Pastelle wrappers by Prairie Fox; title in green and black on cover; title on spine. 200 copies, numbered and signed, bound in gray cloth over boards by Black Oak Bindery; double paper label in green and black on cover. $\$ 4.00 ; \$ 20.00$ signed edition.

49. SPIRITUAL RODEO, by James Margorian; June 1980. 20 unnumbered pages, 612" $\times 4_{1 / 4}^{1 \prime \prime}$. Centaur and Rustic types in black and brown on light brown Strathmore Pastelle paper. 800 copies in light brown Strathmore Pastelle wrappers; title in black and brown on cover. \$3.00.

50. AWKWARD SONG: A COLLECTION OF POEMS, by Allan Komblum; July 1980. 58 pages, 9\%" x 6\%". Goudy Modern and Goudy Open types in black and red on Antique Laid paper. 950 copies in 
Strathmore Grandee Duplex wrappers by Prairie Fox; cover illustration by Phyllis Kornblum; title on spine. 150 copies, numbered and signed, bound in orange linen over boards by Black Oak Bindery; illustration blind-stamped on cover; paper label on spine. $\$ 5.00$; $\$ 20.00$ signed edition.

51. DENTAL FLOSS, Number Four, ed. by Allan Kornblum; July 1980. 16 unnumbered pages, $9^{\prime \prime} \times 64^{\prime \prime}$. Centaur types in black and orange on Curtis Ragston paper. 425 copies in orange Strathmore Grandee wrappers; cover illustration in orange by Dave Morice. This issue completes volume one, with all subsequent volumes to be numbered, beginning with number five. $\$ 2.00$.

52. A VISIT FROM ST. ALPHABET, by Dave Morice; November 1980. 20 unnumbered pages, $5^{\prime \prime} \times 6^{1 / 2}$. Poliphilus types on Strathmore Pastelle paper; four color illustrations by the author; title page in black, red, and green alphabet border. 1,850 copies in vermillion Beckett Cambric wrappers; illustration and title in gold on cover. $\$ 5.00$.

53. CANCIONES, by Antonio Machado, trans. by Robert Bly; December

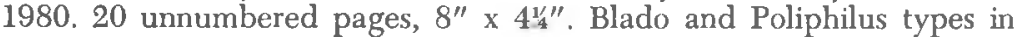
black and green on Strathmore Pastelle paper. 1,350 copies in green Ingres-Fabriano wrappers; cover calligraphy in gold by Sandy Gourlay. 150 copies, numbered and signed, on Rives, bound in green IngresFabriano over boards; cover calligraphy repeats unsigned edition; paste endpapers. $\$ 4.00 ; \$ 30.00$ signed edition.

54. A KEEPSAKE MARKING THE ACQUISITION OF FOUNDERS MEMORIAL LIBRARY'S ONE MILLIONTH VOLUME; September 9, 1980. 24 unnumbered pages, 9 ${ }^{\prime \prime 2}{ }^{\prime \prime} \times 6^{\prime \prime}$. Bulmer and ATF Bulmer types on Classic Laid paper; photographs from Byron's POEMS ON VARIOUS OCCASIONS by Barry Starle; title page drawing by Hilda Itkonen. 2,500 copies in orange Classic Laid wrappers; title in black and dark orange on cover. Printed for Northern Illinois University.

INLAND (excerpt), by Jerald Bullis; April 1980. Broadside, 7\%" $\mathrm{x}$ 14\%". Centaur and Arrighi types in royal blue and black; 150 numbered and signed copies on Shinsetsu paper; sold at Midwestern Writer's Festival and Book Fair. $\$ 2.00$.

IN THE ATTIC, by Donald Justice; April 1980. Broadside, 7 ${ }^{\prime \prime}$ x 10\%2". Centaur and Arrighi types in brown and black; 150 numbered and signed copies on Shinsetsu paper; sold at Midwestern Writer's Festival and Book Fair. \$2.00.

[Untitled], by Faye Kicknosway; April 1980. Broadside, 7\%" x 101/2". Centaur and Arrighi types in gold and black; 150 numbered and signed copies on Shinsetsu paper; sold at Midwestern Writer's Festival and Book Fair. \$2.00.

THE NUCLEAR AGE (excerpt), by Tim O'Brien; April 1980. Broadside, 7\%" $\times 10 \frac{1}{\prime \prime} "$. Centaur and Arrighi types in red and black; 150 numbered and signed copies on Shinsetsu paper; sold at Midwestern Writer's Festival and Book Fair. \$2.00. 
TELL ME A RIDDLE (excerpt), by Tillie Olsen; April 1980. Broadside, $73^{\prime \prime \prime} \times 10 \% 2$. Centaur and Arrighi types in gray and black; 150 numbered and signed copies on Shinsetsu paper; sold at Midwestern Writer's Festival and Book Fair. \$2.00.

GOUDY, by Frederick W. Goudy; June 1980. Broadside, 10" x 5". Goudy Modern types and Goudy Lombardic Initial in red; 500 copies on Strathmore Imprint paper; distributed to friends of the press.

SIXTEEN BROADSIDES. Printed for readings at the Walker Art Center, Minneapolis, Minnesota, 1979-80. All copies printed on varying shades of Canson Mi Tientes. 125 numbered and signed copies; $\$ 2.00$ at the reading, $\$ 4.00$ after the reading. 54 complete sets of numbered and signed edition laid in folded envelope of white Fabriano, with label on cover by Al Buck; distributed to authors appearing in the series and to friends of the press; a few sets sold for $\$ 64.00$. 26 complete sets, lettered and signed, laid in a gray cloth covered box, with label on front; box by Prairie Fox; $\$ 160.00$ per set. Printed for Bookslinger.

LIVING, excerpted from ENORMOUS CHANGES AT THE LAST MINUTE, by Grace Paley. Broadside, 9\%" $\times 12^{3 / \prime}{ }^{\prime \prime}$. Perpetua types and Libra initial.

[Untitled], by William S. Burroughs. Broadside, 978" x 12\%" types.

LOVE LOVE LOVE AGAIN, by Philip Whalen. Broadside, 97" $\mathrm{x}$ 12*". Perpetua types.

OR ANYTHING TO BREAK THINGS UP, by Jane McCauley. Broadside, 97:" x 12\%". Perpetua types.

TWO ELEGIES FOR WENDY PARRISH, by Alvin Greenberg. Broadside, 978" x 12\%". Perpetua types.

BEANS AND FISH, by Alison Knowles. Broadside, 97" x 12\%". Perpetua and Vaudeville types.

THE CIRCUS, by Lon Otto. Broadside, 97/" $\mathrm{x}$ 12\%4". Perpetua and Ornamented types.

COMING BACK ALIVE, by Brigitte Frase. Broadside, 9\%" x 12\%". Perpetua types.

STARMAN AND THE TWO SISTERS, excerpted from RABBIT BOSS, by Thomas Sanchez. Broadside, 97" x 12\%". Perpetua and Hadriano types.

WHAT'S DEAD?, by Allen Ginsberg. Broadside, 9\%" x 12\%". Perpetua and Rheiner Script types.

[Untitled], by Meridel Le Sueur. Broadside, 97" x 12\%". Perpetua Initial and Perpetua types.

[Untitled], by Pauline Oliveros. Broadside, 97/" x 12\%". Perpetua types and zinc block of author's handwriting.

TELL ME A RIDDLE (excerpted), by Tillie Olsen. Broadside, 97" x 12\%". Perpetua types. 
SUNNY MARCE, by Donald Barthelme. Broadside, 9\%" x 12\%". Collage by author.

ANTIC QUATRAINS, by Jackson Mac-Low. Broadside, 97/" x 123". Perpetua and Tuscan Stellar types.

AIRPLANE POEM, by Jerome Rothenberg. Broadside, 978 x 123". Perpetua types.

\section{1}

55. CHARMS, by Jonathan Cott; January 1981. 24 unnumbered pages, $6^{1 / 2}=4_{1 / 4}^{1 / 2}$. Poliphilus and Blado types on Ingres-Fabriano paper. 850 copies in black Ingres-Fabriano wrappers; cover has a cut-out heart revealing title printed in Cordon type on vermillion paper. $\$ 4.00$.

56. DROLES DE JOURNAL, by Carl Rakosi; February 1981. 32 unnumbered pages, $8^{\prime \prime} \times 62^{\prime \prime}$. Bulmer and Vaudeville types in black and yellow on Curtis Tweedweave paper; title page in black and yellow, with red border. 1,350 copies in beige Curtis Tweedweave wrappers; title in burnt orange, with yellow borders, on cover; title on spine. 150 copies, numbered and signed, on Rives Light paper, bound in brown cloth over boards by Prairie Fox; paper label in black and red on cover. $\$ 5.00 ; \$ 30.00$ signed edition.

57. HOW SPRING COMES, by Alice Notley; March 1981. 56 pages, $11^{\prime \prime}$ $\mathrm{x}$ 63:" Ehrhardt types on Curtis Tweedweave paper; title page drawing in black and red by George Schneeman. 900 copies in blue Strathmore Grandee Duplex wrappers by Prairie Fox; title on cover and spine. 100 copies, numbered and signed, bound in blue cloth over boards by Black Oak Bindery; Karakusa paper label in black and red on cover. $\$ 7.50 ; \$ 30.00$ signed edition.

58. MERCURY: A SHORT STORY, by Jonis Agee; April 1981. 20 unnumbered pages, $7^{\prime \prime} \times 7 \% "$. Weiss types on Frankfurt White paper; illustrations in gold by Robert Ferguson; title page in black, gold, and green. 850 copies in pale green Strathmore Brigadoon wrappers; illustration and title in black and gold by Robert Ferguson on cover. 50 copies, numbered and signed by author and illustrator, bound in olive green silk over boards by Black Oak Bindery; paper label in gray and gold on cover. $\$ 7.50 ; \$ 30.00$ signed edition.

59. RE-EXAMINATION OF FREEDOM, by Ruth Krauss; June 1981. 12 unnumbered pages, $82^{\prime \prime} \times 10 \xi^{\prime \prime}$. Perpetua types in light blue on Fabriano White paper. 335 copies, signed by author and artist, in Rives BFK wrappers; four-color intaglio cover printed by James L. Ochs. $\$ 20.00$.

60. HEARTBREAK HOTEL, by Tom Clark; November 1981. 14 unnumbered pages, Japanese fold, $5^{\prime \prime}$ x 5". Goudy Modern and Goudy Open types on Masa paper; illustrations in light brown by author. 500 signed copies in Indian Bengal wrappers with Japanese binding by Prairie Fox. 50 copies marked For Review and not for sale. $\$ 7.50$. 
61. ASPARAGUS, ASPARAGUS, AH SWEET ASPARAGUS, by Faye Kicknosway; November 1981. 48 pages, $8^{\prime \prime} \times 5^{\prime \prime}$. Italian Olde Style types on Curtis Tweedweave paper; drawings in green by the author. 1,200 copies in green wrappers by Prairie Fox; green Curtis Tweedweave endpapers; drawing in green on cover by author; title on spine. 100 signed copies on Curtis Ragston, quarter-bound in boards by Black Oak Bindery; binding not completed at the time checklist compiled. $\$ 7.50 ; \$ 30.00$ signed edition.

62. PURE NOTATIONS, by Steve Levine; December 1981. 34 pages, $10^{\prime \prime} \times 64^{1 \prime \prime}$. Centaur and Hadriano types on Curtis Tweedweave paper; title page illustration by Louise Hamlin, hand colored by Al Buck. 550 copies in blue Curtis Tweedweave wrappers; illustration and title in black by Louise Hamlin on cover. 70 copies, numbered and signed, on Curtis Ragston paper, in cloth over boards; binding not completed at the time checklist compiled. $\$ 6.00 ; \$ 30.00$ signed edition.

63. MANNA, by Cid Corman; December 1981. 12 unnumbered pages, 6/4 $\times 3$ 3,8. Ehrhardt and Salem types in black and brown on Curtis Tweedweave paper. 250 signed copies in light brown Canson $\mathrm{Mi}$ Tientes wrappers; title on cover. Distributed to friends of the press.

64. HOW MICKEY MADE IT, by Jayne Anne Phillips; May 1981. 24 unnumbered pages, $10^{\prime \prime} \times 64^{\prime \prime}$. Italian Olde Style types on pink Strathmore Pastelle paper; illustrations in gray by Gaylord Schanilec. 1,000 copies in wrappers; first state of binding in gray Strathmore wrappers with title on cover, 50 copies; second state of binding in Strathmore wrappers with cover in black, pink, and white by Deborah Freedman, preferred by author. 150 copies, numbered and signed, on Ragston, bound in gray cloth over boards; paper label on cover. 26 copies, lettered and signed by author and artist, on Rives, quarter-bound in gray cloth with pink Murehitome paper sides; paper label on cover; bindings by Black Oak Bindery; each of the 26 copies contains a paragraph, handwritten by author, that was to have been the second paragraph, but was deleted by Phillips. Printed for Bookslinger. $\$ 6.00$; $\$ 35.00$ edition of $150 ; \$ 65.00$ edition of 26 .

65. PEACE ON EARTH, by John Taggart; September 1981. 78 pages, 6:4" $\times$ 66/4". Estienne types on Curtis Tweedweave paper; illustrations in light green by Brad Graves; title page illustration in light green. 850 copies in pea green Curtis Tweedweave wrappers; illustration in green on cover; title and publisher on spine; variant edition, for the Toothpaste Press does not list publisher on spine. Printed for the Turtle Island Foundation. \$5.95.

NIGHT WORK, excerpted from DANGLING IN THE TOURNEFORTIA, by Charles Bukowski; May 1981. Broadside, 6 $\gamma_{2}^{\prime \prime}$ x 4/2 ${ }^{\prime \prime}$. Goudy Modern and Goudy Open types in white; 700 copies on black Ingres-Fabriano. Printed for Bookslinger and distributed at 1981 American Booksellers Association meeting.

CHARACTER IS FATE, excerpted from HEARTBREAK HOTEL, by Tom Clark; May 1981. Broadside, 5" $\times 8^{\prime \prime}$. Optima types in black 


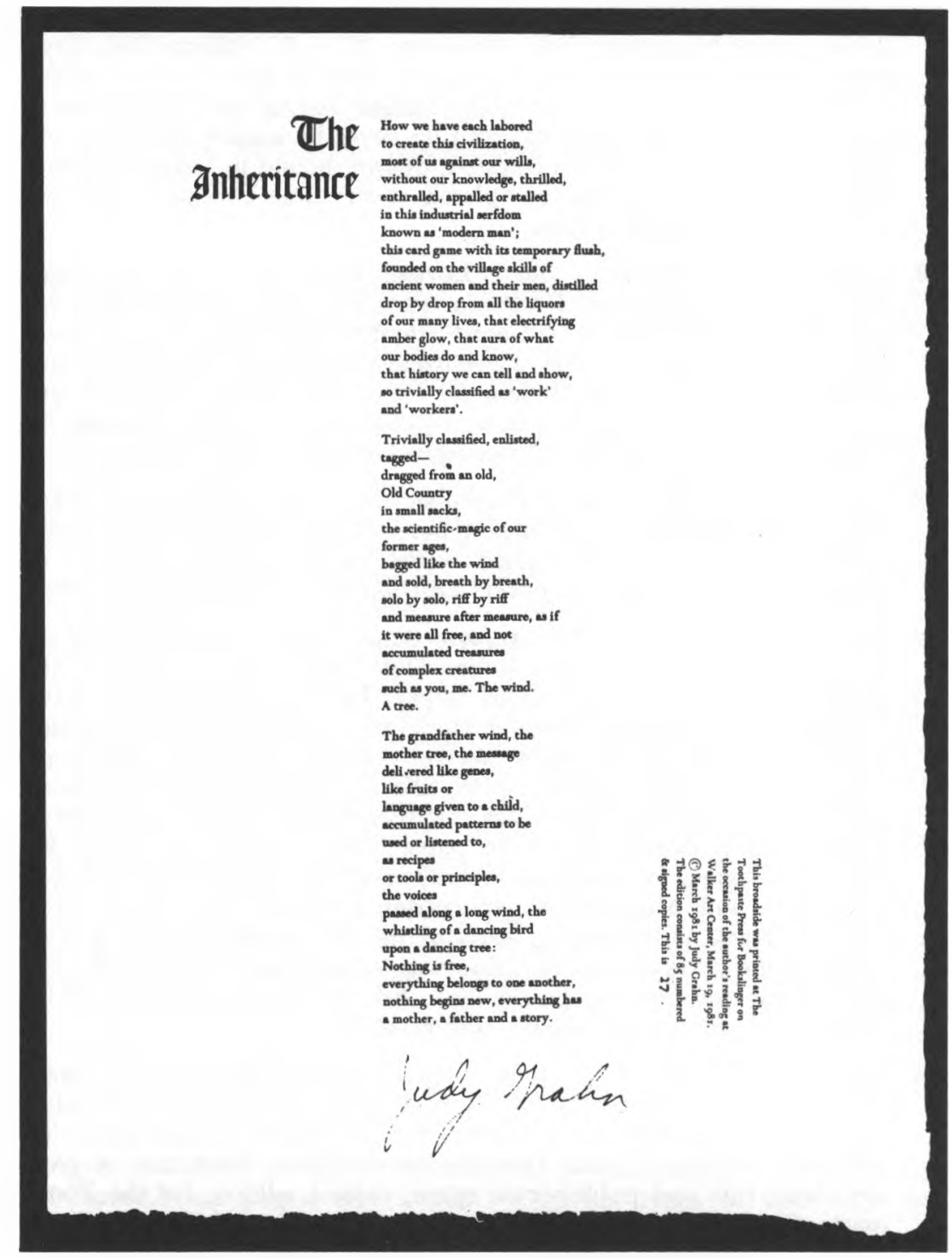

Judy Grahn's "The Inheritance" is one of 20 broadside poems printed by the Toothpaste Press for Bookslinger Editions in St. Paul. It forms part of the Walker Art Center Reading Series 1980-1981. 
and pale blue; 1,100 copies on Ingres-Fabriano. Printed for Bookslinger and distributed at 1981 American Booksellers Association meeting.

[Untitled], by Charles Olson; May 1981. Broadside, 5" x $8^{\prime \prime}$. Italian Olde Style types in black and burnt orange; 1,100 copies on Curtis Ragston; printed for Bookslinger and distributed at 1981 American Booksellers Association meeting.

TWENTY BROADSIDES. Printed for readings at the Walker Art Center, 1980-81. All copies printed on varying shades of Fabriano Roma. 85 numbered and signed copies; $\$ 3.00$ at the reading. 53 complete sets of numbered and signed edition laid in maroon covered box, with label on front, by Prairie Fox; $\$ 166.50$ per set. Printed for Bookslinger.

CALL \& RESPONSE, by Amiri Baraka. Broadside, 9/2" x 13". Goudy Modern types.

A POET DIES, excerpted from THE BOOK OF NODS, by Jim Carroll. Broadside, 9 $y^{\prime \prime}$ × $13^{\prime \prime}$. Goudy Modern and Flash Bold types.

[Untitled], by Diane di Prima. Broadside, 9\%" x 13". Goudy Modern types and ornate initial.

HOMETOWN, by Jayne Anne Phillips. Broadside, 9 $\frac{12}{\prime \prime}$ x 13". Goudy Modern and Vaudeville types.

AN EXCERPT FROM CHAPTER X OF THE DAY DADDY DIED, by Alan Burns. Broadside, 9 $y_{2}^{\prime \prime}$ x 13". Goudy Modern and Coronet Bold types.

DEATH OF A HEN, by Marisha Chamberlain. Broadside, 91/2" x 13". Goudy Modern and Goudy Open types.

STILL LIFE, by Margaret Hasse. Broadside, 9 ${ }_{2}^{\prime \prime}$ x 13". Goudy Modern and Arborette types.

TWO MEDITATIONS: NIAGARA FALLS \& LAKE ERIE, by John Barth. Broadside, 9 $\frac{1}{2} "$ x 13 ". Goudy Modern and Salem types.

IMAGINE YOU ARE A CRAFTSMAN, by Philip Gallo. Broadside, $9 y^{\prime \prime}$ x 13". Goudy Modern and Rustic types.

MENDING, by Deborah Keenan. Broadside, 9 $y_{2}^{\prime \prime}$ x 13". Goudy Modern and Libra types.

CLEANING MORELS, by Thomas Dillon Redshaw. Broadside, 9\%” x 13". Goudy Modern and Latin Ornate types.

DAWN SONG, by Thomas McGrath. Broadside, 9 9:2" x 13". Goudy Modern and Hadriano types.

PEACHES, by Diane Wakoski. Broadside, 9 $\frac{12}{2}$ x $13^{\prime \prime}$. Goudy Modern and Cooper Engraved types.

THE INHERITANCE, by Judy Grahn. Broadside, 9\%" ${ }^{\prime \prime} \times 13^{\prime \prime}$. Goudy Modern types.

LAST DAYS, by Margaret Atwood. Broadside, 9\%” $x$ 13". Goudy Modern and Coronet Bold types. 
SCHEDULE FOR ANOTHER PLACE, by the Four Horsemen: Paul Dutton, Steve McCaffrey, bp Nichol, and Raphael Burreta Rivera. Folded broadside, 9\%" x 13". Goudy Modern and Goudy Open types; rubber stamp illustrations.

CONVERSATION: FOR ROBERT LOWELL, by Ai. Broadside, 9y" $x$ 13". Goudy Modern and Outline types.

ONE OF MY TREES HAS CAUGHT THE MOON, by Michael Dennis Browne. Broadside, 9/2" x 13". Goudy Modern types.

FOR DAN SPELL, by Robert Ferguson. Broadside, 9\%" x 13". Goudy Modern and Optima types.

INTERLUDE, by Anna Wasecha. Broadside, 9\%" x 13". Goudy Modern and Broadway types. 